\title{
Correction to: In silico structural homology modelling of EST073 motif coding protein of tea Camellia sinensis (L)
}

\author{
K. H. T. Karunarathna ${ }^{1,2^{*}}$, N. H. K. S. Senathilake ${ }^{1}$, K. M. Mewan³ ${ }^{3}$ O. V. D. S. J. Weerasena ${ }^{1}$ and S. A. C. N. Perera ${ }^{4}$
}

\section{Correction to: J Genet Eng Biotechnol 18, 32 (2020) \\ https://doi.org/10.1186/s43141-020-00038-6 \\ Following publication of the original article [1], the authors identified an error in the Acknowledgements section. \\ The updated Acknowledgements section is given below and the changes have been highlighted in bold typeface.}

\section{Acknowledgements}

Authors appreciate Tea Research Institute of Sri Lanka (TRISL) for their supporting to receive the grant. Authors thank the emeritus Professor EH Karunanayake and Professor Kamani HTennekoon for their guidance.

The original article [1] has been corrected.

\section{Author details}

${ }^{1}$ Institute of Biochemistry, Molecular Biology and Biotechnology, University of Colombo, Colombo, Sri Lanka. ${ }^{2}$ Current address: Department of Biosystems Technology, Faculty of Technology, University of Ruhuna, Matara, Sri Lanka. ${ }^{3}$ Department of Biotechnology, Faculty of Agriculture and Plantation Management, Wayamba University of Sri Lanka, Makandura, Gonawila, Sri Lanka. ${ }^{4}$ Department of Agricultural Biology, Faculty of Agriculture, University of Peradeniya, Peradeniya 20400, Sri Lanka.

Published online: 06 January 2022

\section{Reference}

1. Karunarathna KHT, Senathilake NHKS, Mewan KM et al (2020) In silico structural homology modelling of EST073 motif coding protein of tea Camellia sinensis (L). J Genet Eng Biotechnol 18:32. https://doi.org/10. 1186/s43141-020-00038-6

The original article can be found online at https://doi.org/10.1186/s43141020-00038-6.

\footnotetext{
${ }^{*}$ Correspondence: thissa1234@gmail.com

${ }^{2}$ Current address: Department of Biosystems Technology, Faculty

of Technology, University of Ruhuna, Matara, Sri Lanka
}

Full list of author information is available at the end of the article

\section{SpringerOpen}

(c) The Author(s) 2021. Open Access This article is licensed under a Creative Commons Attribution 4.0 International License, which permits use, sharing, adaptation, distribution and reproduction in any medium or format, as long as you give appropriate credit to the original author(s) and the source, provide a link to the Creative Commons licence, and indicate if changes were made. The images or other third party material in this article are included in the article's Creative Commons licence, unless indicated otherwise in a credit line to the material. If material is not included in the article's Creative Commons licence and your intended use is not permitted by statutory regulation or exceeds the permitted use, you will need to obtain permission directly from the copyright holder. To view a copy of this licence, visit http://creativecommons.org/licenses/by/4.0/. 